\title{
ANALYSIS ON PRAGMATIC FORCE OF DECLARATIVE UTTERANCES IN FILM ENTITLED "AVATAR"
}

\author{
Eko Widianto, Suparno, Teguh Sarosa \\ English Education Department \\ Teacher Training and Education Faculty \\ Sebelas Maret University of Surakarta
}

\begin{abstract}
Email: echowidi@gmail.com
Abstract: This is a descriptive qualitative research. The data sources are the manuscript and video of "Avatar" film. From the sources, the researcher takes 40 declarative utterances uttered by the main character (Jake Sully) to be analyzed. The research goals are 1) to identify the contexts of declarative utterances, 2) to identify the hearer's responses of declarative utterances, 3 ) to explain the pragmatic force of declarative utterances viewed from the illocutionary force. Before define the force, the researcher explains the context for a better understanding about the speaker's intention. The results of this research are, 1) every utterance has its own context: situation, participants, ends, act sequence, key, instrumentalities, norms, and genre, 2 ) the hearer's responses are words response and act response, 3) utterance's function reflects the pragmatic force, those 40 declarative utterances bring various forces; suggesting, appointing, reporting, requesting, claiming, thanking, asking, complaining, apologizing, confirming, blaming, ordering, advising, and sentencing.
\end{abstract}

Keywords: pragmatic, speech act, illocution, declarative

\section{INTRODUCTION}

Human beings are created to need each other naturally. They need to interact to fulfill their needs. To accomplish that reason human beings create communication. Through communication, they make efforts to get the wants they had expected. Adler and Rodman (2006: 4) state that communication refers to the process of human beings responding to the symbolic behavior of other persons.

Communication occurs in different times and places. In its occurrence, there is a goal which speaker wants to achieve. Every word produced by speaker contains meaning which is addressed to hearer. According to Davis (2003: 553), meaning consists in the expression of ideas, and the meaning is determined by the idea expressed. To cover an intended meaning to hearer, a speaker needs to pack language into expressions which represent everything in his mind. Every expression has different function depending on its goal, and the form of expressions is often we call as utterance. According to Huang (2007: 11), an utterance is the use of particular piece by certain people in certain opportunity: in the form of word, a phrase, a sentence or a sequence sentence.

A word can convey a meaning, but it also brings ambiguity. What words mean is determined in some ways by what speaker means by them and what speaker means is 
determined in some ways by his goal (Grice in Davis, 2003: 7). To prevent ambiguous meaning, a speaker should deliver his idea decisively to make hearer gets what he really means. And to conduct certain meaning, speaker can adjust words with the context. Situation around an utterance interferes in determining meaning. Ekman et al. (1989) in Anderson Guerrero (1998: 463) define context as the social and physical environment in which communication occurs and includes the preceding and consequent facial behaviors as well as body positions and movements, words and vocal tones, the nature of setting, what has happening previously and who else is present. The study of meaning based on context is called pragmatics.

In communication, an utterance is expressed in linguistic form called sentence. There are three basic-sentence types proposed by Leech (1983: 114); declarative, interrogative, and imperative. Declarative is a form of sentence which has been regarded as the basic sentence form. Because of being basic, it can be extended in ways that other forms of sentence cannot and it has very wide range of illocutionary force. Declarative commits the speaker to the truth of the expressed proposition, so declarative can be formed from performative verbs like; assert, state, declare, claim, etc. Commonly, declarative sentence is formed in statement (Cruse, 2000: 337).

There are many media to do communication; direct or indirect communication. Film can be categorized as a medium to do indirect communication. Largely, it is a tool of film maker to deliver a message to the audience. According to Whitman and Boase (1983: 10), communication is the process of transferring information, ideas, emotions, skills, etc. Film is a visual language made of visual/ images sequence as symbols having meaning inside of each images are presented (Douglass and Harnden, 1996: 251-252).

Conversations between characters in a film represent humans' communication in the real world, and so do the communications which occur in a film entitled "Avatar". "Avatar" is a science fiction film produced by James Cameron. It is released by $20^{\text {th }}$ Century Fox on December 18, 2009 and claimed as the most successful film since it won so many awards including The Best Writer category. So, the researcher chooses the declarative utterances in film to be analyzed. The film is set in the year 2154 on Pandora, a fictional Earth-like moon in a distant planetary system. Humans are engaged in mining Pandora's reserves of a precious mineral known as Unobtanium, while the Na'vi-the sapient and sentient race of humanoids indigenous to the moon-resist the colonists' expansion, which threatens the continued existence of the Na'vi and the Pandoran ecosystem. The film's title refers to the remotely controlled, genetically engineered human-Na'vi bodies used by the film's human characters to interact with the indigenous population.

In "Avatar" film, there are many characters involved in many conversations. Each conversation contains various speech. To limit the research, the researcher analyses the pragmatic force of declarative utterances uttered by the main character (Jake Sully).

The utterance "This low gravity makes you soft." is an example of declarative utterance. It is uttered by Colonel Quaritch in the gym when Jake comes to commit his 
order. Quaritch utters the utterance to Jake when they meet at the first time. But, what does Quaritch really mean? Does he just state that Jake is being soft because gravitation? Or he implies certain purpose in the statement. The utterance is an example of declarative utterance that is very likely containing pragmatic force. To identify the force, we need to view all components of the utterance.

Pragmatics is a branch linguistic study of meaning based on its function in communication. Leech (1983: 1) states that pragmatics is how language is used in communication. While according to Griffiths (2006: 6), pragmatics is the study of utterance meaning. In a communication, speaker may conduct his intention in various ways, so consider the context of communication is being very important to make sure that what speaker really means can be perfectly conducted to hearer.

Speech acts as one of the domains of pragmatics. It is divided into three categories; locutionary, illocutionary, and perlocutionary act. Locutionary is the actual words performed by the speaker in saying something to deliver meaning. Then illocutionary act is defined as the implicit intention of the speaker in saying something. And perlocutionary act is defined as the act performed by the hearer as the effect of illocutionary. Searle in Leech (1983: 105-107) groups speech acts based on their functions dealing with the illocutionary goal; assertives, directives, commissives, expressive, and declaration. Every utterance brings certain illocutionary function; and it calls illocutionary force. Illocutionary and social goal of an utterance make up the pragmatic force.

\section{RESEARCH METHODS}

The purpose of the research is to analyze declarative utterances in film entitled "Avatar" based on the context and identify the linguistic form, meaning, and their illocutionary force by using speech acts under the scope of Pragmatics study.

The researcher uses descriptive qualitative method in executing this research. Surakhmad (1994: 147) defines descriptive method as a method of research uses some procedures in researching something; collecting, arranging or classifying, analyzing and interpreting the data, and in the end drawing its conclusion. And, Johnson and Christensen (2000: 17) define qualitative method as a research that largely depends on the collection of non-numerical data; words and pictures.

This descriptive qualitative research is done by finding, selecting, analyzing the data, and finally drawing the conclusion. In this research, the researcher describes the utterances and analyzes the context of every declarative utterance uttered by the main character (Jake Sully) in the film entitled "Avatar". The context is analyzed to classify the speech acts of the utterance. From the speech acts classification, the researcher defines the utterance literal meaning, speaker's meaning, and the hearer's response. From those definitions, it is obtained the function of the declarative utterance as the interpretation of pragmatic force.

The researcher uses document (the authentic manuscript) and video (film) to collect data for this research. From the sources, the researcher takes 40 declarative utterances uttered by the main characters of "Avatar" film (Jake Sully) as the data of this 
research. As we know, manuscript is the base of all conversation and acts of the characters of a film.

The process of collecting data were: (1) watching and replaying the film entitled "Avatar" to understand the story and the contents of the film; (2) reading the "Avatar" manuscript of the film entitled "Avatar"; (3) finding all declarative utterances uttered by the main character (Jake Sully) in the film manuscript entitled "Avatar"; (4) checking the declarative utterances in the manuscript with the declarative utterances uttered in the video (or subtitle); (5) selecting the matching utterances of the manuscript and the video; (6) studying the current situation of each declarative utterance.

The data of the research is analyzed using descriptive qualitative method. Miles and Huberman (1994: 10-11) state that the method needs three current flows of activity; data reduction, data display, and conclusion.

Data reduction means process of selecting, focusing, simplifying, abstracting, and transforming the data that appears in a research. In this research, the researcher does some steps to reduce the data: (a) watching film entitled "Avatar" to understand its story, context, situation, plot, and circumstances; (b) reading the film manuscript for several times to find declarative utterances uttered by Jake Sully; (c) collecting whole declarative utterances uttered by Jake Sully in the film entitled "Avatar"; (d) selecting 40 utterances from the whole declarative utterances as the sample.

An example of declarative utterance is "This low gravity makes you soft". The utterance is uttered by Quaritch in "Avatar" film. Colonel Quaritch utters it in gym area when Jake comes to commit his order. Quaritch knows that Jake is a new soldier in Pandora. He tells Jake about the dangerous of Pandora and wants Jake to be careful.

The utterance uttered by Quaritch is classified as a declarative utterance. Based on the conversation above, the context of the declarative utterance are: (1) Situation: the dialogue occurs on Pandora planet, at the daylight in the gym area when Colonel Quaritch is in a physical exercise; (2) Participants: the dialogue involves Jake and Colonel Quaritch; (3) Ends: Quaritch wants Jake to be aware about the dangerous of Pandora; (4) Act sequence: Quaritch advises Jake to be aware of being in Pandora; (5) Key: seriously; (6) Instrumentalities: Quaritch speaks orally to Jake; (7) Norms: Quaritch's statement implicitly means that Jake is soft because of situation in Pandora; (8) Genre: joke.

Based on the Quaritch's utterance performance according to Austin's classification of act performance in language, it is identified as follows: (a) the locutionary act: "This low gravity makes you soft" (a statement that Jake is soft because of the situation in Pandora); (b) the illocutionary act: Quaritch is advising Jake to be aware of being in Pandora; and (c) The perlocutionary act: Jake is aware about the dangerous of Pandora.

To identify the pragmatic force of the declarative utterance uttered by Quaritch, it can be done by comparing the literal meaning, function, expected effect, and the hearer's response. From the analysis before it gets: (1) Declarative utterance: "This low gravity makes you soft"; (2) Sentence literal meaning: Jake is being soft because of the situation in Pandora; (3) Function/ utterance meaning: an 
advice for Jake to be aware of being in Pandora; (4) Expected effect: Jake is aware about the dangerous of Pandora; (5) Hearer's response: there is no straight response, Jake just listens carefully.

From the literal meaning, function, expected effect, and the response of the declarative utterance, there is no direct relation of the literal meaning and function. The literal meaning of the utterance doesn't reflect the function. It includes to the indirect speech act. Jake doesn't give response to Quaritch; he just listens carefully. The utterance doesn't indicate that Jake is being soft because of the situation in Pandora, but it is an advice for Jake to be aware about the dangerous of Pandora.

From the data analysis, the researcher makes conclusions about the research. It is obtained after the researcher identifies the context of utterance, discovers the literal meaning, function, the expected effect, and considers the hearer's response to interpret the pragmatic force of each declarative utterance produced by Jake Sully in the film entitled "Avatar".

\section{RESEARCH FINDINGS AND DISCUSSIONS}

The authentic manuscript of Avatar film consists of 151 pages, and the video's running time is about 157 minutes. In the manuscript and video, there are 120 declarative utterances produced by Jake Sully. The researcher randomly takes 40 utterances as the sample to be analyzed. Each utterance is analyzed in a datum, and it's marked by the number of datum and the page of the film manuscript.

To detect pragmatic force of declarative utterance, context of utterance is the main consideration. The context determines the performance of acts when an utterance produced, as the explanation of Austin (1962) in Horn and Ward (2006: 54- 55), that there are three acts performed when a language is put to use; locutionary, illocutionary, and perlocutionary acts. To expand context of an utterance, the researcher uses the theory of Hymes in Fasold (1990: 44-46); Situation, Participants, Ends, Act sequence, Key, Instrumentalities, Norms, and Genre. Moreover, to classify the act of an utterance, the researcher uses the theory of Searle in Leech (1983: 105-107) that there are five types of speech act based on the illocutionary force; Assertives, Directives, Commissives, Expressives, and Declarations.

The main point of the research analysis is the description of the pragmatic force of declarative utterances that uttered by Jake Sully in the film entitled "Avatar". The description covers the context and act classification to determine the function of an utterance as its pragmatic force.

This research focuses on the pragmatic force of declarative utterance which arises from the social goal and the illocutionary goal of an utterance. Shortly, social and illocutionary goal of an utterance are reflected by the function of speaker uttering the utterance to the speaker. In this research, declarative utterances are taken from the manuscript-video matching of Avatar film. The analysis is focused on the declarative utterances produced by Jake Sully; the main character of Avatar film. The researcher finds120 utterances that 40 of them are analyzed as the data of this research.

The analysis of each utterance is started by show the description of the utterance, from 
the description the researcher expands the context of the utterance; situation, participants, ends, act sequence, key, instrumentalities, norms, and genre. Then the researcher classifies the utterance into locutionary act, illocutionary act, and perlocutionary act. From the classification, the researcher concludes the utterance's literal meaning and its function and then puts it in a table. The table is also functioned to show the expected effect to the hearer and hearer's response. From the table, the researcher defines the pragmatic force of the utterance as the conclusion of each datum.

From those 40 data, the researcher finds that declarative utterance brings various forces:

Table 1 Declarative utterances' function and illocutionary force

\begin{tabular}{lllll}
\hline No. & Function & Force & $\boldsymbol{\Sigma}$ Data & Percentage \\
\hline & & & & \\
1. & Suggestion & Suggesting & 2 & $5 \%$ \\
2. & Decision & Appointing & 4 & $10 \%$ \\
3. & Report & Reporting & 4 & $10 \%$ \\
4. & Request & Requesting & 12 & $30 \%$ \\
5. & Claim & Claiming & 3 & $7.5 \%$ \\
6. & Thank & Thanking & 1 & $2.5 \%$ \\
7. & Question & Asking & 1 & $2.5 \%$ \\
8. & Complaint & Complaining & 3 & $7.5 \%$ \\
9. & Apologize & Apologizing & 2 & $5 \%$ \\
10. & Confirmation & Confirming & 2 & $5 \%$ \\
11. & Accusation & Blaming & 1 & $2.5 \%$ \\
12. & Order & Ordering & 3 & $7.5 \%$ \\
13. & Advice & Advising & 1 & $2.5 \%$ \\
14. & Verdict & Sentencing & 1 & $2.5 \%$ \\
& Total & & 40 & $100 \%$ \\
\hline
\end{tabular}

Table 1 indicates that declarative utterance has wide range of function and illocutionary force. From 40 utterances, there are found 14 kinds of function and illocutionary force. The data above shows that declarative utterance as the basic sentence form is so expandable on the using. The speaker can convey his meaning using varied utterance by adjusting the declarative sentence with the context.

Based on the function of the utterances, the researcher classifies the forces into five types of illocutionary based on Searle's theory. The five types are assertives, directives, commisives, expressives, and declarations. 
Table 2 The illocutionary types of utterances

\begin{tabular}{|c|c|c|c|}
\hline No. & Illocutionary Type & $\Sigma$ Data & Percentage \\
\hline 1. & Assertives & 12 & $30 \%$ \\
\hline 2. & Directives & 19 & $47.5 \%$ \\
\hline 3. & Commisives & 0 & $0 \%$ \\
\hline 4. & Expressives & 4 & $10 \%$ \\
\hline \multirow[t]{2}{*}{5.} & Declarations & 5 & $12.5 \%$ \\
\hline & Total & 40 & $100 \%$ \\
\hline
\end{tabular}

The 40 forces of declarative utterances are classified into five types; assertives, directives, commisives, expressives, and declarations. First, the assertive type includes suggesting, reporting, claiming, and complaining. Second, the directives type includes requesting, asking, confirming, ordering, and advising. Then the expressives type includes thanking, apologizing, and blaming. And the last, the declarations type includes appointing and sentencing.

\section{CONCLUSION, IMPLICATION, AND SUGGESTION}

Some conclusions are drawn based on the problems statement and data analysis. Firstly, the researcher finds out that the context of an utterance determines the conduction of meaning from speaker to hearer. Every word, phrase, and sentence uttered has different context. When a sentence is uttered in different places or in different times, it will bring different meaning. The declarative utterances produced by Jake Sully in film entitled "Avatar" have their own context; situation, participants, ends, act sequence, key, instrumentalities, norms, and genre. From those 40 utterances taken, every utterance has its own context which is different from another utterance.
Secondly, the hearer's responses of Jake Sully's declarative utterance are many and varied. The varied responses are influenced by Jake's meaning by those declarative utterances. The responses are not only organized as word, phrase, or sentence, but the some responses are formed in acts and some others do not give any response. The words responses are like statement and question, while act responses are such eying, nodding, attacking, etc.

Finally, Jake Sully as the main character mostly uses declarative utterances that affecting the hearers to do something according to his mind. From the 40 declarative utterances uttered by Jake Sully, there are obtained 14 kinds of force; suggesting $(5 \%)$, appointing $(10 \%)$, reporting $(10 \%)$, requesting $(30 \%)$, claiming $(7.5 \%)$, thanking $(2.5 \%)$, asking $(2.5 \%)$, complaining $(7.5 \%)$, apologizing $(5 \%)$, confirming $(5 \%)$, blaming $(2.5 \%)$, ordering $(7.5 \%)$, advising $(2.5 \%)$, and sentencing $(2.5 \%)$. The finding shows that the majority forces of Jake's declarative utterances are formed in directives type (requesting, asking, confirming, ordering, and advising). The requesting force becomes the most dominant force implied in Jake's declarative utterances. 
Declarative utterance is often used in daily conversation. People usually use it to express what they intend. Thus, the study about declarative utterance is needed to explore the using of the utterance in social interaction.

Constructing simple sentence is introduced in Senior High School. Declarative sentence is one of basic sentence forms that should be included in the materials. As the most common sentence form, declarative becomes the primer choice for people to state something. The more serious teaching and enrichment about declarative are given in the third level of Senior High School. In this level, students are more productive in constructing sentences; they can express their mind easily in the form of statement (declarative). Thus, declarative is the most usable form in producing utterance. As analyzed in this research, declarative utterance brings so varied functions in the application. In teaching and learning activity, declarative utterances can be applied as teacher's instruction and as teaching materials.

A teacher needs to create appropriate instruction to make the learning activity runs well as the expectation. Thus, declarative utterances are the alternative choices. Declarative utterances can be applied to create instructions with varied function. As the result of this research, a declarative utterance can be functioned as suggestion, decision, report, request, claim, thank, question, complaint, apologize, confirmation, accusation, order, advice, and verdict. Beside those functions, declarative utterances have many more functions as their pragmatic force.

The activity in classroom is applicable situation for language. Speech acts are components of language that can be inserted in the communication between teacher and students to enrich the substances of the communication. One of them is declarative utterance; it can be applied to create a meaningful utterance. There are not only teachers who can apply the utterances, but also students can use the utterances in the class.

\section{BIBLIOGRAPHY}

Adler, Ronald B and Rodman, George. 2006. Understanding Human Communication, Ninth Edition. New York: Oxford University Press.

Anderson, Peter A and Guerrero, Laura K. 1998. Handbook of Communication and Emotion: Research, Theory, Applications, and Contents. USA: Academic Press.

Cruse, Alan. 2000. Meaning in Language: An Introduction to Semantics and Pragmatics. New York: Oxford University Press.

Davis, Wayne A. 2003. Meaning, Expression and Thought. Ney York: Cambridge University Press.

Douglass, John S and Harnden, Glenn P. 1996. The Art of Technique: An Aesthetic Approach to Film and Video Production. USA: A Simon and Schuster Company.

Fasold, Ralph W. 1990. The Sociolinguistic of Language. Cambridge: Blackwell

Griffiths, Patrick. 2006. An Introduction to English Semantics and Pragmatics. Edinburgh: Edinburgh University Press. 
Horn, Laurence R and Ward, Gregory. 2006.

The Handbook of Pragmatics. UK:

Blackwell Publishing Ltd.

Huang, Yan. 2007. Pragmatics. New York: Oxford University Press Inc.

Johnson, Burke and Christensen, Larry. 2000. Educational Research: Quantitative and Qualitative Approaches. Boston: A Person Education Company.

Leech, Geoffrey N. 1983. Principles of Pragmatics. New York: Longman Group Limited.

Miles, M. B. and Huberman, A. M. 1994. Qualitative Data Analysis (2 $2^{\text {nd }} E d$.). Thousand Oaks, CA: Sage.

Surakhmad, Winarno. 1994. Pengantar Penelitian Penelitian Penelitian Ilmiah Dasar, Metoda, Teknik. Bandung: Tarsito.

Whitman, Richard F and Boase, Paul H. 1983. Principle and Context: Speech Communication. USA: Macmillan Publishing Inc. 